\title{
A Critical Review of the National University of Lesotho Anti-Plagiarism Policy
}

\author{
Malefetsane Elliot Nketekete \\ Department of Business and Management Development, \\ National University of Lesotho, Lesotho \\ E-mail:me.nketekete@nul.ls/mnketekete@gmail.com
}

Mamoeletsi Limakatso Mojalefa

Department of Business and Management Development, National University of Lesotho, Lesotho

E-mail: mjl.mojalefa@nul.1s/mjlmojalefa@gmail.com

Received: May 4, 2021 Accepted: June 11, $2021 \quad$ Published: June 23, 2021

doi:10.5296/bmh.v9i1.18787ＵRL: https://doi.org/10.5296/bmh.v9i1.18787

\begin{abstract}
Globally, higher education institutions (HEIs) adopt different strategies to curb plagiarism, which undermines the integrity of educational qualifications issued by these institutions. One of the key strategies adopted by HEIs is the development of anti-plagiarism policies. Emerging research from literature do indicate that effective strategies are educational and developmental intended to equip students with skills of acknowledging materials from other sources. Further, research indicates that anti-plagiarism policies reinforce negative attitudes towards plagiarism, hence adopting punitive strategies against the would-be perpetrators. The study reviewed the National University of Lesotho (NUL) anti-plagiarism policy, to determine the type of messages and discourses the policy communicates to its users. The study used document analysis, using the NUL anti-plagiarism policy as the unit of analysis. Content and discourse analysis were applied as research techniques. The study revealed that the policy communicated punitive and moral discourses. These discourses undermine the developmental aspects of academic writing. The study recommends the review of the policy to include educational and developmental discourses that would encourage that students' academic writing is developed. Further, the University should review its policy not only to address students but members of staff.
\end{abstract}


Keywords: anti-plagiarism, National University of Lesotho, organizational theory, plagiarism, plagiarism discourses 


\section{Introduction}

Like other universities globally, the National University of Lesotho (NUL) recognises plagiarism as a serious academic misconduct. In counteracting acts of plagiarism the NUL has developed a policy on cheating and plagiarism. The NUL sees plagiarism, as evil, compromising "the process of fair and equitable evaluation of all students' academic performance and erode the quality and value of degrees conferred by the University" (National University of Lesotho, 2012, p. 1). The university further sees plagiarism as a social menace, destroying the very moral fabric of society, which promotes hardworking and diligence. This it does by reinforcing "the false idea that success in life, can come to those who deviate from community norms and who lack requisite expertise in their chosen career" (National University of Lesotho, 2012, p. 1). The policy prescribes a heavy penalty which prescribes a disqualification of students from a course in which plagiarism was committed. Further, a student transcript indicates 'examinations misconduct' in that particular course, which becomes a stigma for the student for the rest of his or her life.

Despite the heavy penalty imposed on acts of plagiarism, students continue to engage in plagiarism. This may suggest a need to explore the issue of plagiarism within NUL. This becomes necessary, given the growing body of research which indicates that dealing with plagiarism is not as easy as it might be thought, given a number of factors at play, which range from socio-cultural, ethical and educational (Amsberry, 2009, cf. Gunnarsson, Kulesza, \& Pettersson, 2014; Duff, Rogers, \& Harris, 2006, cf. Gunnarsson et al., 2014; Sonfield, 2014; Chunhui, Zhiguo, \& Dongsheng, 2013). The complexity of plagiarism justifies the need to understand its nature and factors contributing to its existence, within a prevailing educational milieu.

Plagiarism policies are important institutional artefacts which reflect the understanding of the institution in relation to plagiarism issue. Plagiarism policies reflect the official position of an institution on plagiarism, its understanding and how it addresses the challenge. Werkel (2021) argues that plagiarism policies are important documents; at they are the means through which universities communicate with students, professors and other staff members and provide guidelines for addressing cases related to plagiarism. Adam, Anderson and Spronken-Smith (2017, p. 18) add that "plagiarism is discursively constructed in university policy documents, or the connections and disconnections between institutional and student understandings of plagiarism in higher education." Brown and Howell (2001) argue that policy statements should be worded appropriately to facilitate clear communication of policy intents against plagiarism.

This paper intended to analyse how plagiarism is portrayed by the NUL plagiarism policy. It further analysed the type of messages the policy communicates to audiences of university's policy. The paper attempted to answer the following questions:

1) What is the structural content of the policy?

2) What are the plagiarism discourses communicated by the policy? 


\section{Literature Review}

\subsection{Plagiarism as a Worldwide Problem}

Plagiarism is a worldwide problem haunting higher education institutions in both developed and developing countries (East, 2010; Gunnarsson, Kulesza, \& Pettersson, 2014; Kauffman \& Young, 2015; Walker \& White, 2014; Chireshe, 2014; Theart \& Smit, 2012; Hu \& Shu, 2020; Bowen \& Nanni, 2021). According to Honig and Bedi (2012, p. 102), "the issue of student plagiarism has generated a great deal of media and research attention and is an increasingly studied phenomenon in higher education research". Plagiarism has been reflected as a very bad phenomenon within higher education sector. A variety of terms have been used to indicate its abhorrent nature: dishonesty, unethical, lack of academic virtue, cheating, moral evil, mental illness, assault on academic integrity, intellectual theft; the list of which is endless (Gunnarsson et al., 2014; Kauffman \& Young, 2015; Sarlauskienea \& Stabingisa, 2014; Sonfield, 2014; Stowers \& Hummel, 2011; Balve, 2014). Despite such portrayal, plagiarism is not generally prosecutable in the courts of law but its consequences and repercussions are far reaching, especially in the world of academia (Sonfield, 2014; Alspach, 2014). According to Alspach (2014) a plagiarised work does not only affect the plagiarist but also a publication media in which the work is published. Once the work is proved to have been plagiarised, this may lead to retraction of such work (Alspach, 2014). Retraction is a growing phenomenon and has attracted a lot of research ( $\mathrm{Hu} \& \mathrm{Xu}, 2020)$. This obviously taints the professional standing of the researcher or author. As Sonfield (2014, p. 81) argues:

While ... plagiarism may not inflict injury or monetary damages upon the authors who are plagiarized, the offenders may receive major damage to, or the loss of, their academic careers. Students found to plagiarize may be punished in some manner, but can usually then move on with their lives. A non-tenured professor who is found guilty of plagiarism will generally not have his or her contract renewed. Even a tenured professor may be subject to termination, or perhaps a lesser form of discipline, after some form of academic investigation and due process. Thus, the consequences of faculty plagiarism are often more substantial that [sic] for copyright infringement.

\subsection{The Concept of Plagiarism}

While plagiarism is regarded as a menace in the higher education sector worldwide, there is generally lack of consensus as to what it means among academia (Sarlauskienea \& Stabingisa, 2014; Stabingisa, Šarlauskienėa, \& Čepaitienèa, 2014). Price (2002, p. 88) notes that "plagiarism is difficult, if not impossible, to define." Sarlauskienea and Stabingisa (2014) attribute its rampancy to the lack of common understanding. According to the authors, the lack of understanding has been demonstrated in the way it is treated. They observe that, it is taken seriously if committed intentionally but differently if it is committed unintentionally (Sarlauskienea \& Stabingisa, 2014). The way it is addressed also reflect the general concensus on its understanding. Some authors advocate punitive measures while others advocate educational and moral approaches (Sonfield, 2014; Gunnarsson et al., 2014; Walker $\&$ White, 2014). Educational and moral approaches are advocated on the understanding that 
plagiarism is not only academic but also socio-cultural phenomenon (Sonfield, 2014; Honig \& Bedi, 2012; Walker \& White, 2014; Sarlauskienea \& Stabingisa, 2014). This therefore, calls for the adoption of a "comprehensive and clear definition of plagiarism and various types of it with practical examples could help the academic community to develop plagiarism prevention." (Sarlauskienea \& Stabingisa, 2014, p. 638). It has also been suggested that a broad definition of plagiarism is helpful in analysing the plagiarised work (Sarlauskienea \& Stabingis, 2014).

Owen and White (2013, p. 14) define plagiarism as "the use of another author's words or ideas without appropriate acknowledgement". Though simple and straightforward, this definition does not actually indicate the actions the plagiarist is likely to engage in to warrant that he or she has plariarised. The definition advanced by the Pennsylvania Public University as referred to by Sarlauskienea and Stabingis $(2014$, p. 641) indicates the actions which warrant plagiarism. Noting the Pennsylvania Public University's definition, Sarlauskienea and Stabingis (2014, p. 641), indicate that people plagiarize if they:

- $\quad$ present the work, which is not written by you;

- copy answers or text from other student and present them as of your own;

- quote or paraphrase other works not indicating the original author;

- quote data without references to original sources;

- present the ideas of other authors as of your own;

- fake references or use improper references;

- provide presentation, programme or other work of another person with minimal changes.

Analysis of definitions of the concept tends to revolve around 'acknowledgement'. Hence this leads to conclusions that one has either committed plagiarism deliberately or unintentionally (Walker \& White, 2014; Sarlauskienea \& Stabingis, 2014). In their definition, Owens and White (2013, p. 14) add that:

plagiarism could result from a failure to understand how to acknowledge a source, carelessness in doing so, or a deliberate attempt to present another person's work as your own. The latter case might be termed 'dishonest plagiarism', whereas referencing ignorance or carelessness is often described as leading to 'negligent plagiarism.

Such definitions reflect the complexity of plagiarism, making its detection even more complex. One cannot easily detect whether a plagiarist has plagiarised intentionally or unintentionally. This is more so, in the light of factors which literature has documented as contributory to its widespread occurrence in higher education sector. Thus, the issue of intentionality is neither here nor there, as Barrón-Cedeño, Vila, Martí \& Ross (2013, p. 417) observe that plagiarism "is often the outcome of a conscious process".

Literature identifies different forms of plagiarism which have influence on its definition. Kauffman and Young (2015) identify conventional and digital plagiarism. Conventional 
plagiarism refers to academic dishonesty involving copying work from other sources other than from Internet. On the other hand, digital plagiarism involves using material from the Internet by means of cutting and pasting. The plagiarism is gaining momentum given the powerful tools that exists within Internet environment that allow copy and paste function (Kauffman \& Young, 2015; Stowers \& Hummel, 2011). These tools allow "students to use the CP function to mash up materials they find online and present it as their own work" (Kauffman \& Young, 2015, p. 44). Perrin (2009) (cited by Okoro, 2014, p. 174) identifies "whole-paper plagiarism, copy-and- paste plagiarism, and careless plagiarism." Martin (2004) (cf. Barrón-Cedeño et al., 2013, p. 918) identifies plagiarism "of ideas, of references, of authorship, word by word, and paraphrase plagiarism." According to Martin, plagiarism of ideas consists of the use of other peoples' ideas, knowledge, or theories without proper acknowledgement. In the same manner, with "references and authorship, citations and entire documents are included without any mention of their authors" (Martin cf. Barrón-Cedeño, p. 918). "Word by word plagiarism, also known as copy-paste or verbatim copy, consists of the exact copy of a text (fragment) from a source into the plagiarized document" (Martin cf. Barrón-Cedeño, p. 918). Paraphrase plagiarism refers to the use of different words expressing the same meaning, without acknowledging the source. Source acknowledgment consists of paraphrasing, quoting, or summarizing statements with appropriate identification, followed by an elaboration of the authors' views or perspectives to provide context (Perrin, 2009; Larkham, 2002; Culwin, 2001; cited by Okoro, 2011, p. 174). Owens and White (2013, p. 14) also add person-to-person plagiarism which occurs when students in the same course copy each other's assignments, and resource plagiarism occurs when students copy from printed materials or the Internet in general.

\subsection{Strategies Adopted to Address Plagiarism}

The pandemic nature of plagiarism has necessitated higher education institutions to develop anti-plagiarism policies intended to curb it by introducing punitive measures to discourage it (Kaktiňš, 2014). It has been observed that such policies, no matter how punitive they may be, they are not effective (Heckler, Forde, \& Bryan, 2013; Kauffman \& Young, 2015; Insley, 2011; Walker \& White, 2014). Despite the deemed evils of plagiarism and the need to curb it, literature suggests other approaches towards addressing the problems other than punitive measures. It has been argued that punitive approaches to plagiarism are not appropriate given its complex and multifaceted nature (Amsberry, 2009, cf. Gunnarsson, et al., 2014). Some authors have suggested that it is a pandora box and needs to be handled with care (Sutherland-Smith, 2005). A number of factors contribute to its complexity. First, it has been suggested that it is not only committed by students but also lecturers who are supposed to mentor and teach students on proper principles of research (Sonfield, 2014; Honig \& Bedi, 2012; Walker \& White, 2014; Sarlauskienea \& Stabingisa, 2014). Further, lecturers may not be willing or lack requisite skills in determining students' plagiarism and ensuring avoidance (Chireshe, 2014; Alsmadi, AlHami, \& Kazakzeh, 2014; Chireshe, 2014; Maio, Dixon, \& Yeo, 2019). Maio, Dixon and Yeo (2019) observe that in most cases lecturers avoid pursing students who engaged in plagiarism. Secondly, it has been observed that plagiarism is more or less socio-cultural, moral and ethical, linguistic and educational issue (East, 2010; 
Sonfield, 2014; Chunhui, Zhiguo, \& Dongsheng, 2013; Amsberry, 2009 cf. Gunnarsson, Kulesza, \& Pettersson, 2014, p. 413). Plagiarism is based on notions "originality, authenticity, authorship, and proprietorship of language and ideas" (Hu \& Lei, 2012, p. 814), which are "not universally shared but are culture-specific and historically situated" (Hu \& Lei, 2012, pp. 814-815). There have been suggestions that students, mainly from developing world, who are not familiar with the Western academic traditions are likely to engage in acts of plagiarism (Sonfield, 2014; Stowers \& Hummel, 2011; Leask, 2006). Duff et al. (2006) (cited by Gunnarsson et al., 2014, p. 414) assert that "notions of plagiarism are constructed culturally and the remedy for plagiarism is not necessarily punitive, but lies in making Western expectations of scholarship clear". Plagiarism is regarded as the Western construct (Sentleng \& King, 2012). Balve (2014, p. 82) notes, "the extent and degree of plagiarism varies depending on the cultural context. ... One question is whether or not it is appropriate to apply the definition of the Western problem to all cultures." Being a moral issue, plagiarism comes into being as a result of cheating and deception (Hu \& Lei, 2012; Gunnarsson, 2014). Sarlauskienea and Stabingisa (2014) observe the difficulty in understanding the expected appropriate behaviour. Kaktinš (2014, p. 129) reinforces the socio-cultural aspect of plagiarism as follows:

plagiarism, is so crucial as to transcend the internal classifications in the institution and community. In the process, the experiential categories — student, teacher, etc.- become subsumed by a more urgent (moral, ethical, academic) imperative and reconfigured as interpersonal categories of those who are academically "ethical" versus those who are not, i.e., those who are "included" in the community, and those who are excluded.

In reflecting its moral and ethical aspects Clegg and Flint (2006) (cf. Borg, 2009, p. 417) observe that discussions on plagiarism "frequently take place in an atmosphere of moral panic and condemnation." Added to the list, the issue of intentionality contributes to the complexity of plagiarism. Research and debate on plagiarism has suggested different types of plagiarism, which on a whole try to establish whether plagiarising was intentional or not (Sarlauskienea \& Stabingisa, 2014). Sarlauskienea and Stabingisa (2014, p. 642) distinguish between the two as follows:

Unintentional plagiarism may be defined as the loss of memory while writing or crypto-amnesia, which is the illusion of the mind, that the author created the idea himself, even though he has read or heard about it somewhere. Even experimental research proved how implied past memories may be repeated unintentionally. ...An intentional plagiarism is when a student has planned to deceive.

Walker and White (2014, p. 675) agree with Sarlauskienea and Stabingisa (2014), in that:

Plagiarism refers at once to the deliberate intention to cheat and to the unintentional failure to acknowledge one's sources (usually due to a lack of understanding about academic culture and the importance of scholarly attribution). Both forms of plagiarism may appear to differ in degree insofar as they both constitute a failure to acknowledge work that is not one's own. However, insofar as the first constitutes a deliberate intention to mislead, it undermines one of the most basic codes of ethics. 
Recognising the complex nature of plagiarism, there have been arguments advanced to adopt other strategies other than punitive ones (Sonfield, 2014; Gunnarsson et al., 2014; Walker \& White, 2014). Adopting the alternative strategies recognises that plagiarism is not only the responsibility of students alone but also of the lecturers and institutions (Walker \& White, 2014). Walker and White (2014, p. 675) state:

...plagiarism is a complex phenomenon that requires an ongoing calibration of the relative skills and experiences of both students and staff in response to their respective personal and institutional pressures.

Literature suggests ethical and pedagogical strategies as alternative to punitive measures (Walker \& White, 2014; Chunhui et al., 2013; Kaktinšs, 2014; Insley, 2011; Ouden \& van Wijk, 2011). These strategies are preventive in nature and facilitate the effective management of plagiarism (Insley, 2011). On the other hand, punitive measures "promote plagiarism as students are inclined to test their lecturers" (Insley, 2011, p. 184). The adoption of ethical strategies is premised on the assumption that plagiarism is an academic dishonesty (Sonfield, 2014; Chireshe, 2014). Chunhui, Zhiguo and Dongsheng (2013) refer to these strategies as honest and ethical education. The authors advocate that students need to be educated "about the nature of plagiarism, and the reasons why it is unacceptable" (Chunhui et al., 2013, p. 272). Further, students should know that copying other people's work contributes to their failure (Chunhui et al., 2013). Accordingly, the ethical strategies address the proper code of conduct when borrowing ideas from others and emphasise the promotion of expected behaviour and rules of conduct expected from a scholar (Walker \& White, 2014). In addition to ethical model, educational or instructional model has been recommended (Gunnarsson et al., 2014; Insley, 2011). Educational strategy has been proved to be effective in reducing the rate of plagiarism (Okoro, 2011; Chen \& Ullen, 2011). The strategy is intended to equip students, through educational experience, with academic skills such as communicative and linguistic (Gunnarsson et al., 2014) appropriate citing, paraphrasing, referencing and academic integrity (Stabingisa et al., 2014).

\subsection{Plagiarism Policies}

Plagiarism policies are the primary documents which outline and communicate definitions and preventative strategies on plagiarism. Policies are regarded as communicative devices which provide guidance to students and academic staff members (Merkel, 2021). While institutional policies on plagiarism may be viewed as authoritative on issues related to plagiarism, Price (2002) is of the view that care should be taken depending on how the policy is constructed given the complex nature of plagiarism. According to Price (2002) plagiarism is a context sensitive phenomenon which institutional policies should reflect such a nature. The emerging studies in institutional plagiarism policies address various aspects of policy, from conception to implementation. Some studies have explored students understanding of their respective plagiarism policies across different countries (Magaisa, 2013; Gullifer \& Tyson, 2014; Munir, Siddique, \& Asif, 2012).

Magaisa (2013) studied how a plagiarism policy was implemented within a South African university. Magaisa's study found out that lecturers did not implement actions and processes 
suggested by the policy. Further, a majority of lecturers were not aware whether their students knew about the policy in place and did not take responsibility of making students aware. Gullifer and Tyson (2014) studied whether students in an Australian institution of higher education were familiar with plagiarism policies. They found out that $52 \%$ of those that returned questionnaires agreed to having read the policy and male were significantly likely to have read the policy. In addition, distance learners were likely to have read the policy than on-campus students. Ramzan, Munir, Siddique and Asif (2012) investigated awareness of plagiarism policy among university students in Pakistan. Their study found out that there was low level of awareness about plagiarism policies and processes amongst the students.

Another important area of research has been on the study of substantive nature of institutional plagiarism policies - what they communicate to their intended audience. Merkel (2021) analysed plagiarism policies of nine Colleges at the University of Iowa applying critical discourse analysis (CDA). Merkel (2021) found out that both institutional and faculty level policies covered more of moral and regulatory discourses. Hu and $\mathrm{Su}$ (2017) made similar findings in eight Chinese universities. In applying discourse analysis, the authors found punitive and moral discourses dominant. Adam, Anderson and Spronken-Smith (2017) found similar results in New Zealand. From the analysis of policy documents, they found moral and regulatory discourses dominating the policy landscape. Merkel (2021) opined that by focusing mainly on moralistic and regulatory tendencies, policies tend to confuse students. Such confusion is brought about by the academic immaturity of students (Merkel, 2021). The moral discourse of policy has been defined as a way of portraying the guilty nature of engaging in plagiarism acts, and determining the punishment mechanisms for those found guilty (Adam et al., 2017). Adam et al. (2017, p. 19) capture the essence of moral discourses in the manner:

Moral discourses are revealed through the use of law- or crime-related language (e.g., theft, breach, copyright) or through references to immorality or illegality (e.g., dishonest, unethical, misconduct). Within moral discourses, plagiarism is constructed as cheating, and as involving deliberate and morally reprehensible behaviours.

Punitive stance could also be indicated by the use of anti-plagiarism software to detect and deter plagiarism ( $\mathrm{Hu} \& \mathrm{Su}, 2017)$. A second discourse, regulatory, acknowledges plagiarism as both intentional and unintentional (Adam et al., 2017). The intervening institutional strategies are in the form of policies, rules and regulations (Adam et al., 2017; Kaposi \& Dell, 2012; Price, 2002). The common terms used in reflecting this discourse are "rules, guidelines, and academic traditions" (Adam et al., 2017, p. 22). Regulatory discourse enforces procedures to be followed in circumventing plagiarism ( $\mathrm{Hu} \& \mathrm{Su}, 2017$ ). According to $\mathrm{Hu}$ and Sun (2017) this orientation appeared highly idealistic as it assumed that students would follow prescribed procedures smoothly without experiencing problems - that is to say procedures are problem free. Hu and Sun (2017) observed that the authors of the analysed policy documents, in eight universities in China, appeared to lack an understanding of plagiarism as they failed to provide comprehensive definitions of plagiarism, failed to recognise different forms of plagiarism and the contested nature of the concept. Such shortcoming might have the potential to deny students opportunity to learn about plagiarism 
(Hu \& Sun, 2017). They further observed that the policies provided for the oversight bodies, which only react after the observation of the plagiarism acts. Thus, "Little policy attention was given to faculty's active involvement in creating and sustaining an educative process for students" (Hu \& Sun, 2017, p. 65). The authors conclude by observing that inadequate policies and non-existence of ethics education will continue to be the main cause of plagiarism among students, given that Chinese students are not necessarily English-speaking students. This was also observed by Akbar and Picard (2019) in their study of university policy on plagiarism in Indonesia. The found out that "the definition of plagiarism remains broad and the levels of plagiarism and sanctions for plagiarism remain undefined" (Akbar \& Picard, 2019, p. 1). A third discourse, academic, or developmental type, acknowledges students engagement in plagiarism as the result of ignorance and they have to be skilled (Adam et al., 2017; Kaposi \& Dell, 2012). Strategies within this discourse are special courses related to academic writing in respective fields. The common strategies are to address plagiarism a context specific phenomenon (Price, 2002).

Another important study was undertaken by Kaktinšs (2014) in examining Australian universities plagiarism policies applying appraisal theory (AT) as a method of investigation. Appraisal theory applies words, phrases and structures to analyse attitudes and interpersonal meanings in different discourses employed by writers or speakers (Wei, Wherrity, \& Zhang, 2015). AT consists of three subsystems of appraisals, namely attitude, graduation and engagement that provide the basis for evaluative position (Kaktinšs, 2014; Wei et al., 2015; Ross \& Caldwell, 2020; Bednarek, 2007). Attitude is regarded as central to the AT (Kaktinšs, 2014; Wei et al., 2015). Based on Martin and White (2005) exposition, Wei et al. (2020, p. 236) summarise the domains as follows:

Attitude takes a central position. It is concerned with our feelings, including emotional reactions, judgments of behaviour and evaluation of things; Engagement deals with sourcing attitudes and the play of voices around opinions in discourse; Graduation attends to grading phenomena whereby feelings are amplified and categories blurred.

In using AT to analyse policy documents, Kaktinšs (2014) found out that policy documents communicated both positive and negative messages about plagiarism, to a larger extent portrayed moralistic and punitive nature of Australian plagiarism policies. In some fewer cases, educative or developmental discourses were observed.

\subsection{Locating Plagiarism Policies within Organizational Theory}

Plagiarism policies are important communicative devices, reflecting institutional attitudes towards plagiarism. Within organizational thinking, policies, in particular plagiarism policies, are regarded as "manifestations of powerful institutional rules which function as highly rationalized myths" (Meyer \& Rowan, 1977, quoted by Zucker, 1987, p. 450). Organizational theory provides useful insights into understanding the organizational forces related to implementation of innovations and practices (Hillebrand, Nijholtn, \& Nijssen, 2011). Organizations are constantly struggling for recognition within their institutional environment, and in so doing shape their beliefs, rules and norms (Björkman, Fey, \& Park, 2007). Berthod (2016, p. 1) further provides that organizational theory enhances "analysis of organizations' 
design and conduct." Within organizational theory, institutions are "understood as taken-for-granted beliefs, rules, and norms, which shape the creation and spreading of organizational forms, design features, and practices" (Berthod, 2016, p. 1). Munir (2014) reiterates that institutions are all about power, shape our actions. Furthermore, "organizational forms, practices, categories, and so on become reified or "institutionalized" beyond their functional utility, becoming infused with particular meanings that may not have been there, or intended, initially" (Munir, 2014, 1). Institutions are defined as "beliefs, rules, roles, and symbolic elements capable of affecting organizational forms independent of resource flows and technical requirements" (Scott, 1991, quoted by Berthod, 2016, p. 2). Institutions have to contend with both external and internal forces for survival. Digmaggio and Powell (1983) acknowledge different factors that determine the institutional behavior. Firstly, they identify coercive isomorphism whereby powerful organizations like governments impose certain patterns on the organizations. Secondly, mimetic isomorphism, which mainly refers to organizations' response mechanism by copying the practice from their successful counterparts. Lastly, normative isomorphism refers to organizations' actions as professional bodies, which disseminate appropriate patterns.

Applied within the study, anti-plagiarism policies could be seen as action by the NUL to claim its legitimacy within the HEIs environment, by following the trend taken by HEIs worldwide (mimetic and normative isomorphism).

\section{Methodology}

NUL has a plagiarism policy which had been approved in March 2012. It presented as a two-page document, titled Policy and Procedures on Cheating and Plagiarism. It is this document that was the main unit of analysis.

\subsection{Methodological Framework}

Two overarching methodologies have been used, namely, content and discourse analysis. The two methodologies are normally used to interpret textual data (Ocler, 2009). According to Feltham-King and Macleod (2016) discourse analysis "highlights the role of language in constructing reality and the manner in which discourses provide space for particular subject position." The document analysis was employed within the framework of appraisal theory to determine different discourses. In determining policy discourses, Appraisal Theory was used to analyse whether the text was positively or negatively presented (Kaktiņš, 2014). A policy as a text is capable of conveying attitudinal meaning, either explicitly or implicitly (Tilakaratna \& Mahboob, 2013).

\subsection{Data Collection and Analysis}

In collecting and analysing data, key variables and themes emerging from literature by $\mathrm{Hu}$ and Sun (2017) and Merkel (2021) were used. These variables are summarised by Table 1 below. 
Table 1. Plagiarism variables and themes

\begin{tabular}{|c|c|c|}
\hline Variable & Hu \& Sun (2017) & Merkel (2021) \\
\hline Do Document title & $\sqrt{ }$ & \\
\hline Location & $\sqrt{ }$ & $\sqrt{ }$ \\
\hline Targeted stakeholders & $\sqrt{ }$ & \\
\hline Type of academic misconduct & $\sqrt{ }$ & \\
\hline Oversight body & $\sqrt{ }$ & \\
\hline Procedure/Instruction regarding suspected violations & $\sqrt{ }$ & $\sqrt{ }$ \\
\hline Sanction & $\sqrt{ }$ & \\
\hline Use of text-matching software & $\sqrt{ }$ & \\
\hline Teacher responsibilities & $\sqrt{ }$ & \\
\hline Approach \& discourse & $\sqrt{ }$ & \\
\hline Definition & & $\sqrt{ }$ \\
\hline Reference to integrity & & $\sqrt{ }$ \\
\hline Examples of plagiarism & & $\sqrt{ }$ \\
\hline Citation styles & & $\sqrt{ }$ \\
\hline Intent & & $\sqrt{ }$ \\
\hline Tips & & $\sqrt{ }$ \\
\hline Reference to handbooks, website & & $\sqrt{ }$ \\
\hline Number of words per attribution & & $\sqrt{ }$ \\
\hline Common knowledge & & $\sqrt{ }$ \\
\hline Paraphrase & & $\sqrt{ }$ \\
\hline Cross-disciplinary reference & & $\sqrt{ }$ \\
\hline Reference to the learning process & & $\sqrt{ }$ \\
\hline
\end{tabular}

\section{Results and Discussion}

The purpose of the paper was to analyze the NUL plagiarism policy to determine the type of messages it could possibly convey. The results are presented into two categories emerging from policy analysis. Firstly, the overall attitudinal stance is presented and secondly, data for each specific variable is provided using a table.

\subsection{Attitudinal Stance}

Based on the literature reviewed, an Appraisal Theory was applied to determine the overall 


\section{Macrothink}

attitudinal stance the policy adopts. From the textual analysis it emerged that the policy portrayed a negative attitudinal stance. The negative appraisal of the policy tends towards moralistic or punitive denunciation of the would be perpetrators (Kaktiņš, 2014). The introduction part of the policy reflects the attitudinal position of the policy as appraised.

The extract from the policy document, as indicated below, reflects this attitudinal stance.

World-wide there has been a massive growth of Cheating and Plagiarism as a result of the intensity of competition for jobs and also expansion of the Internet. Cheating and plagiarism compromises the process of fair and equitable evaluation of all students' academic performance and erode the quality and value of degrees conferred by the University. Intellectual dishonesty reinforces the false idea that success in life, can come to those who deviate from community norms and who lack the requisite expertise in their chosen careers. In order to protect the integrity of the academic enterprise and also the quality of the degrees conferred by the University, the Senate of the National University of Lesotho has adopted the following policy. [extract1]

\subsection{Thematic Findings}

The study analyses the content of the policy and the findings are summarised as per each variable as shown in Table 2 below: 
Table 2. Variables used to analyse data

\begin{tabular}{l} 
Variable \\
\hline Document title \\
Location \\
Targeted stakeholders \\
Type of academic misconduct/definition
\end{tabular}

Oversight body Findings

Policy and Procedures on Cheating and Plagiarism

Loose two-page document

Students

Cheating: actual or attempted practice of fraudulent or deceptive act for the purpose of improving one's grade or obtaining course credit; such acts also include assisting another student to so.

Plagiarism: a form of cheating which consists of using the ideas or work of another person or persons as if they were one's own without giving proper credit to the source

Procedure/Instruction regarding suspected violations

Instructor/examination officer, department, Vice Chancellor or Senate Committee

Sanction

An instructor of a course or examination officer initiates a meeting with a student or refers a matter to a departmental hearing. An instructor submits an incomplete grade which will stand until the matter is resolved. The instructor or examination officer will produce evidence to substantiate the allegations. Within 36 hours the head of department writes to the candidate informing him or her of the allegations against him/her. The student is advised about the date of the hearing. The concerned department established an ad hoc committee to investigate.

Warning; reduction or cancellation of the grade. Academic sanction involves assigning a grade such as " 0 " or " $F$ ". The transcript for that particular course reflects "examination misconduct". The second sanction is disciplinary sanction which involves suspension or expulsion by the Vice Chancellor or Senate Committee

Use of text-matching software

There is no reference to anti-plagiarism software

Teacher responsibilities No mention

Approach \& discourse

Mostly, the policy reflects moral and regulatory discourses. From the policy analysis, moral discourse is indicated by the employment of the terms such as: "cheating", "fraudulent or deceptive acts", "intent", "gain an unearned academic advantage", "without giving proper credit", "misuse of published or unpublished work", "including Bibliography that were not examined" Regulatory discourse detail procedures followed in dealing with cheating and plagiarism, outlining of different sanctions, namely warning, academic and disciplinary, guidelines on what constitute cheating and plagiarism

Reference to integrity

The policy makes reference to integrity: to protect the integrity of the academic enterprise and also the quality of the degrees conferred by the University, the Senate of the National University of Lesotho has adopted the following policy.

Examples of plagiarism

- $\quad$ examples

- $\quad$ citation styles

- intent

- tips

- $\quad$ reference to handbooks, website

- number of words per attribution

- $\quad$ common knowledge

- paraphrase

- $\quad$ cross-disciplinary reference
- $\quad$ Examples: lack of acknowledging source of ideas; misuse of published or unpublished work as own; failure to use quotation marks when directly borrowing from another; fabrication of references; minimal paraphrasing the expressions of thought by others without appropriate quotation marks.

- Reference to intent is in relation to cheating

- $\quad$ citation styles, tips, reference to handbooks and websites, number of words per attribution, common knowledge and cross-disciplinary reference not covered by the policy No reference to the learning process 


\section{MInstitute Macrothink $_{\text {Int }}$}

The title of the policy was National University of Lesotho: Policy and Procedures on Cheating and Plagiarism. The title itself is self-explanatory, clearly articulating its intended focus. However, its presentation in a two-page format diminishes its significance. It has not been put on the University's website which could make it accessible to students and lecturers. Further, the University has an on-line teaching and learning platform, Thuto. The policy has not been put on Thuto, which is ideally the most appropriate location. Paradoxically, an anti-plagiarism software is integrated within the University on-line platform, but there is not policy to indicate the acceptable percentage for plagiarism.

It has also been observed that the intended audience for the policy is students. This observation could be interpreted as the University's belief that only students are capable of committing plagiarism. This observation is supported by literature (Honig \& Bedi, 2012; Walker \& White, 2014; Sarlauskienea \& Stabingisa, 2014; Sonfield, 2014).

From the analysis, punitive and moralistic discourses tend to be overemphasized in the policy. This is not surprising as the definitions adopted by the policy are too narrow reflecting the punitive and moralistic aspects of plagiarism and cheating. Literature suggests that in order to address the problems of plagiarism and cheating, comprehensive definitions of plagiarism should be adopted (Sarlauskienea \& Stabingisa, 2014; Sonfield, 2014). The emerging strategies that are regarded as effective in addressing the problems of plagiarism such as educational and developmental should be adopted (Gunnarsson et al., 2014; Okoro, 2011; Chen \& Ullen, 2011)

\section{Conclusions}

The study concluded that the policy mainly exhibits negative attitudinal position, promoting punitive and moral aspects. This attitude is further demonstrated by only focusing on students excluding the members of staff, as if its only students who are capable of plagiarism. Literature reports that even members of staff do commit plagiarism. From literature, it has also been observed that moral and punitive strategies against students who committed plagiarism are not effective. It is recommended that:

1) The university should review its anti-plagiarism policy to include both students and members of the staff.

2) Further, the policy should be comprehensive enough to include other aspects such as educational and developmental, aimed at equipping students and members of staff with appropriate skills such as linguistic and writing to avoid plagiarism. Such an attitude will ensure that special courses are offered to students and staff members, to address their emerging needs.

\section{References}

Adam, L., Anderson, V., \& Spronken-Smith, R. (2017). 'It's not fair': policy discourses and students' understandings of plagiarism in a New Zealand university. High Educ., 74, 17-32. https://doi.org/10.1007/s10734-016-0025-9

Alsmadi, I., AlHami, I., \& Kazakzeh, S. (2014). Issues Related to the Detection of Source 
Code Plagiarism in Students Assignments. International Journal of Software Engineering and Its Applications, 8, 23-34.

Alspach, J. G. (2014). A Case of Plagiarism: Lessons for Editors, Authors, Reviewers, Readers, and Plagiarists. Critical Care Nurse, 34(5), 12-16. https://doi.org/10.4037/ccn2014786

Bagraim, J., Goodman, S., \& Pulker, S. (2014). Understanding dishonest academic behaviour amongst business students - the business leaders of the future. Industry \& Higher Education, 28(5), 331-340. https://doi.org/10.5367/ihe.2014.0222

Balve, J. (2014). Authorship, plagiarism and cooperation in higher education Conclusions from experiences with Asian cultures and learning environments. Journal of Asian Pacific Communication, 24(1), 81-93. https://doi.org/10.1075/japc.24.1.05bal

Barrón-Cedeño, A., Vila, M., Martí, M. A., \& Ross, P. (2013). Plagiarism Meets Paraphrasing: Insights for the Next Generation in Automatic Plagiarism Detection. Computational Linguistics, 39(4), 917-947.https://doi.org/10.1162/COLI_a_00153

Berthod, O. (2016) Institutional Theory of Organizations. In A. Farazmand (Ed.), Global Encyclopedia of Public Administration, Public Policy, and Governance. Springer International Publishing AG 2016. https://doi.org/10.1007/978-3-319-31816-5_63-1

Björkman, I., Fey, C. F., \& Park, H. J. (2007). Institutional Theory and MNC Subsidiary HRM Practices: Evidence from a Three-Country Study. Journal of International Business Studies, 38(3), 430-446. https://doi.org/10.1057/palgrave.jibs.8400267

Borg, E. (2009). Local plagiarisms. Assessment \& Evaluation in Higher Education, 34(4), 415-426. https://doi.org/10.1080/02602930802075115

Brown, V. J., \& Howell, M. E. (2001). The efficacy of policy statements on plagiarism: Do they Change students' views? Research in Higher Education, 42(1), 103-118. https://doi.org/10.1023/A:1018720728840

Chireshe, R. (2014). Academic dishonesty: Zimbabwe university lecturers' and students' views. SAJHE, 28(1), 45-59. https://doi.org/10.20853/28-1-325

Chunhui. W., Zhiguo, L., \& Dongsheng, L. (2013). Preventing and Detecting Plagiarism in Programming Course. International Journal of Security and Its Applications, 7(5), 269-278. https://doi.org/10.14257/ijsia.2013.7.5.25

Dias, P. C., \& Bastos, A. S. C. (2014). Plagiarism phenomenon in European countries: Results from GENIUS project. Procedia - Social and Behavioral Sciences, 116, 2526-2531. https://doi.org/10.1016/j.sbspro.2014.01.605

DiMaggio, P. J., \& Powell, W. W. (1983). The iron cage revisited: Institutional isomorphism and collective rationality in organizational fields. American Sociological Review, 48(2), 147-160. https://doi.org/10.2307/2095101

East, J. (2010). Judging plagiarism: A problem of morality and convention. High Educ., 59, 
69-83. https://doi.org/10.1007/s10734-009-9234-9

Gunnarsson, J., Kulesza, W. J., \& Pettersson, A. (2014). Teaching International Students How to Avoid Plagiarism: Librarians and Faculty in Collaboration. The Journal of Academic Librarianship, 40, 413-417. https://doi.org/10.1016/j.acalib.2014.04.006

Heckler, N. C., Forde, D. R., \& Bryan, H. C. (2013). Using Writing Assignment Designs to Mitigate Plagiarism. Teaching Sociology, 41(1) 94-105. https://doi.org/10.1177/0092055X12461471

Hillebrand, B., Nijholt, J. J., \& Nijssen, E. J. (2011) Exploring CRM effectiveness: An institutional theory perspective. J. of the Acad. Mark. Sci., 39, 592-608. https://doi.org/10.1007/s11747-011-0248-3

Honig, B., \& Bedi, A. (2012). The Fox in the Hen House: A Critical Examination of Plagiarism Among Members of the Academy of Management. Academy of Management Learning \& Education, 11(1), 101-123. https://doi.org/10.5465/amle.2010.0084

Hu, G., \& Lei, J. (2012). Investigating Chinese University Students' Knowledge of and Attitudes Toward Plagiarism from an Integrated Perspective. Language Learning, 62(3), 813-850. https://doi.org/10.1111/j.1467-9922.2011.00650.x

Hu, G., \& Xu, S. (2020). Agency and responsibility: A linguistic analysis of culpable acts in retraction notices. Lingua, 247, 102954. https://doi.org/10.1016/j.lingua.2020.102954

Insley, R. (2011). Managing plagiarism: A preventative approach. Business Communication Quarterly, 74(2), 183-187. https://doi.org/10.1177/1080569911404058

Kaktinšs, L. (2014). Appraising plagiarism policies of Australian universities. Text \& Talk, 34(2), 117-141. https://doi.org/10.1515/text-2013-0040

Kauffman, Y., \& Young, M. F. (2015). Digital plagiarism: An experimental study of the effect of instructional goals and copy-and-paste affordance. Computers \& Education, 83, 44-56. https://doi.org/10.1016/j.compedu.2014.12.016

Leask, B. (2006). Plagiarism, cultural diversity and metaphor-implications for academic staff development. Assessment \& Evaluation in Higher Education, 31(2), 183-199. https://doi.org/10.1080/02602930500262486

Merkel, W. (2021). Collage of confusion: An analysis of one university's multiple plagiarism policies. System. https://doi.org/10.1016/j.system.2020.102399

Munir, K. A. (2014). A Loss of Power in Institutional Theory. Journal of Management Inquiry, 1-3. https://doi.org/10.1177/1056492614545302

Mwamwenda, T. (2006). Academic integrity: South African and American university students. The Journal of Independent Teaching and Learning, 1, 34-44.

Ocler, R. (2009). Discourse analysis and corporate social responsibility: A qualitative approach. Society and Business Review, 4(3), 175-186. 
https://doi.org/10.1108/17465680910994182

Okoro, E. A. (2011). Academic integrity and student plagiarism: Guided instructional strategies for business communication assignments. Business Communication Quarterly, 74(2), 173-178. https://doi.org/10.1177/1080569911404064

Olasehinde-Williams, O. (n.d.). Lecturer and student sensitivity to academic dishonesty intervention approaches in a Federal University in Nigeria (pp. 152-182). Ife PsychologIA.

Owens, C., \& White, F. A. (2013). A 5-year systematic strategy to reduce plagiarism among first-year psychology university students. Australian Journal of Psychology, 65, 14-21. https://doi.org/10.1111/ajpy.12005

Sarlauskienea, L., \& Stabingisa, L. (2014). Understanding of plagiarism by the students in HEIs of Lithuania. Procedia - Social and Behavioral Sciences, 110, 638-646. https://doi.org/10.1016/j.sbspro.2013.12.908

Sentleng, M. P., \& King, L. (2012). Plagiarism among undergraduate students in the Faculty of Applied Science at a South African Higher Education Institution. South African Journal of Libraries \& Information Science, 78(1), 57-67. https://doi.org/10.7553/78-1-47

Stabingisa, L., Šarlauskienėa, L., \& Čepaitienėa, N. (2014). Measures for plagiarism prevention in students' written works: Case study of ASU experience. Procedia - Social and Behavioral Sciences, 110, 689-699. https://doi.org/10.1016/j.sbspro.2013.12.913

Stowers, R. H., \& Hummel, J. Y. (2011). The use of technology to combat plagiarism in business communication classes. Business Communication Quarterly, 74(2), 164-169. https://doi.org/10.1177/1080569911404406

Sutherland-Smith, W. (2005). Pandora's box: academic perceptions of student plagiarism in writing. Journal of English for Academic Purposes, 4, 83-95. https://doi.org/10.1016/j.jeap.2004.07.007

Theart, C. J., \& Smit, I. (2012). The status of academic integrity amongst nursing students at a nursing education institution in the Western Cape. Curationis, 35(1), 27. https://doi.org/10.4102/curationis.v35i1.27

Tilakaratna, N. L., \& Mahboob, A. (2013). Appraisal in the time of conflict: Coding evaluation through textual and contextual analysis. Linguistic and Human Sciences, 8(1), 63-90. https://doi.org/10.1558/lhs.v8i1.63

Walker, C., \& White, M. (2014). Police, design, plan and manage: Developing a framework for integrating staff roles and institutional policies into a plagiarism prevention strategy. Journal of Higher Education Policy and Management, 36(6), 674-687. https://doi.org/10.1080/1360080X.2014.957895

Zucker, L. G. (1987). Institutional Theories of Organization. Annual Review of Sociology, 13, 443-464. https://doi.org/10.1146/annurev.so.13.080187.002303 


\section{Macrothink}

\section{Copyrights}

Copyright for this article is retained by the author(s), with first publication rights granted to the journal.

This is an open-access article distributed under the terms and conditions of the Creative Commons Attribution license (http://creativecommons.org/licenses/by/4.0/). 